\title{
Morphological and Physiological Characteristics of the Representatives of Melilotus Albus and Melilotus Officinalis, Growing on the Territory of Kalmykia
}

\author{
V. I. Dordzhieva, T. V. Voloshina, and K. S. Ochirova
}

Kalmyk State University named after B.B. Gorodovikova, Elista, Russia

\section{Abstract}

A comparative analysis of leaf blades of two kinds of clover (Melilotus albus, Melilotus officinalis) growing on the territory of Kalmykia has been carried out. Identified diagnostic features in the anatomical structure of the leaves of each species. The parameters of leaf tissue are set. The results of the work give an idea of the degree of plasticity of a characteristic of a leaf plate of two types of clover. Demonstrated features of plates of the same species can be equally, as well as specific for this species,

Corresponding Author:

V. I. Dordzhieva

viktoria_dord@mail.ru

Received: 25 October 2019

Accepted: 15 November 2019

Published: 25 November 2019

Publishing services provided by

Knowledge E

(c) V. I. Dordzhieva et al. This article is distributed under the terms of the

Attribution License, which permits unrestricted use and redistribution provided that the original author and source are credited.

Selection and Peer-review under the responsibility of the AgroSMART 2019 Conference Committee.

\section{G OPEN ACCESS} and adaptive variability, due to which the plant has adapted to life in arid conditions. The water regime, indicators of transpiration and productivity of the clover were studied. Changes in physiological parameters were determined before the onset of the summer drought and at its height. The established morphological and physiological characteristics of the two species of clover allow them to be defined as plants that are well adapted to growing under the arid conditions of Kalmykia. The combination of the structural features of the clover with its physiological capabilities, valuable feeding properties and a positive effect on the soil, testifies to the effectiveness of the use of clover in the lean, saline areas of the region. The obtained data can be used in further systematic studies of the genus Melilotus, as well as in planning reclamation measures.

\section{Introduction}

In many countries, various varieties of clover are cultivated in order to improve soil characteristics during crop rotations, to obtain high-quality honey, a highly nutritious food, as well as raw materials for the manufacture of unique medicines [1, 2]. Selection works are aimed at breeding varieties characterized by an increase in the number of flowers and flowering time, an increase in green mass, an increase in the density of nodule bacteria per unit of the underground part of the plant. In addition, great attention is paid to the study of high adaptive plasticity of quantitative signs of clover, changes in the ratios of chemicals of plant materials during germination in certain conditions [3, 4]. Representatives of clover find their application in various branches of human life, which necessitates the complete illumination of the biological characteristics of this plant. 


\section{Statement of the Problem}

The soils of the republic are usually salted to one degree or another. Vast territories are occupied by saline, salt marshes or sands. The flora of Kalmykia was formed under the influence of a sharply arid climate, saline soils and high mineralization of natural groundwater. The dominant species in the steppes are turf cereals -- koeleria, wheatgrass, feather grass, the Volga fescue as well as herbaceous polycarpic plants and subshrubs -- wormwood and chaste trees. On sands or saline soils, wormwood, chaste trees and camphorosmeae, highly resistant to various stresses, dominate. Kalmyk steppes are the main wealth of the republic, as long since the most important branch of agriculture here is grazing. The territory of natural pastures occupies more than 85 $\%$ of the surface of lands intended for agriculture. Wild grasses are year-round food for farmed animals; therefore, protection and restoration of the steppes is an important and top priority for the region. The steppe ecosystem is characterized as mature and highly resistant. But its fragility before anthropogenic impact is obvious. An example of such a fact is the existence of the progressive "Black lands" desert in Kalmykia. In addition to the desert, in the region there is a problem of increased load on the natural pastures, the consequence of which is the gradual impoverishment of the grass stand and the increase in the level of water-soluble salts in the soil. Huge funds are spent by the republic on the restoration of plant associations, on stopping or delaying the moving dunes of the "Black Lands". Planting psammophiles, soil salting plants are regularly created here, and the growth of their wild populations is monitored. The main hopes are associated with the species of Pamirian winterfat, kochia, and calligonum $[5,6]$.

On the territory of Kalmykia, sweet clover representatives are characteristic components of many plant communities. Sweet clover is characterized by many physiological features, which in the conditions of our republic allow us to define it as a valuable plant. The value of sweet clover lies primarily in its effect on soil substrates. It is known that Kalmykia lands are distinguished by rather low fertility, but the sweet clover, as a representative of leguminous plants, contributes to the increase of nutrients in the soil. An important aspect is the simplicity of sweet clover to the soil substrates, as well as its high tolerance to various stress effects -- high and low temperatures, solar insolation, drought, and increased concentration of water-soluble salts in soil solutions $[7,8]$.

The long vegetative period is characteristic for sweet clover, in the conditions of Kalmykia it begins in early spring and ends in the middle of autumn. The grass of sweet clover, rich in proteins and other nutrients is a valuable pasture feed for farm animals. In addition, clover perfectly preserved in the composition of grass hay throughout the 
winter. In this regard, the goal of our work: the study of the structural and physiological features of the representatives of Melilotus albus and Melilotus officinalis growing on the territory of Kalmykia.

\section{Materials and Methods}

Copies of white clover (Melilotus albus) and clover of yellow (Melilotus officinalis) were collected in June 2017 in the vicinity of the city of Elista of the Republic of Kalmykia. Each sample consisted of 20 orthotropic shoots. The morphological analysis of the sample was carried out according to the standard technique [9]. Anatomical studies conducted by traditional methods of light microscopy. Cross sections of the leaf blade were made with a razor by hand. Viewing the sections was performed using a biolam microscope. Anatomical drawings are made using the drawing apparatus RA-4. Preparation of cuts, measurements, description of drawings, determination of physiological parameters are made according to generally accepted methods [10,11]. For the analysis, photosynthetic organs that have completed growth and are located on medium formations along the height of the main shoot were selected.

\section{Discussion of the Results}

Under Kalmykia conditions, the shoots of Melilotus albus and Melilotus officinalis reach a height of about $80--86 \mathrm{~cm}$. About 19--23 side shoots are laid on the plants, and the branching of the main stem begins, as a rule, from the middle third. The total number of lateral photosynthetic organs, which are formed on a single copy, is about 27--31 pieces. The central leaves of the complex leaves of the white clover can be characterized by the following parameters: a leave shape is oval and lanceolate; and their edges are provided with cloves; the linear dimensions of the leaves are about $4 \mathrm{~cm}$ by $1.3 \mathrm{~cm}$ (length and width). The central leaves of the complex leaves of the yellow clover can be described approximately as well: the shape of the leaves is wide and oval; the edges are provided with fine teeth, and the linear dimensions of the leaves are on average about $3.8 \mathrm{~cm}$ by $2.2 \mathrm{~cm}$ (length and width). Thus, the main difference in the morphology of vegetative organs between representatives of two species can be attributed to the shape of the central leaves of the complex leaves and the size of their teeth at the edges of the plates. These parameters are distinguished by significant stability and are of qualitative character, while both other signs (height of shoots, number of side 
branches and number of laying leaves) have a wide range of variability and relate to quantitative indicators to a greater degree.

The generative part of the clover shoots is represented by long inflorescences (approximately 7--10 cm), each of which is composed of many small flowers (about 61--64 pieces). It was established that the time of ripening of a single bud -- from the moment of its formation to full blooming -- is about 5.5 days for the flowers of the clover of medicinal, and 6.5 days for the flowers of the clover of white. In addition, a separate flower of a yellow clover functions for 5 days, and a flower of the second species -a little less -- 4.5 days. The duration of flowering of one copy of Melilotus officinalis is about 55 days, while this number is slightly lower for representatives of Melilotus albus -- approximately 50 days.

The study of anatomical sections of leaf growth plates of representatives of two species of Melilotus growing on the territory of Kalmykia, made it possible to make the following description. The plates are characterized by a dorsoventral variety of the photosynthetic parenchyma, starting immediately under the primary integumentary tissues. Cells of the palisade mesophyll are elongated, compactly and orderly arranged. The number of layers of palisade cells is two. The cells of the spongy mesophyll have rounded shapes, are freely located relative to each other, forming between themselves well-defined air-holding spaces. However, a dense subepidermal layer of rounded cells, localized directly above the lower integumentary tissue, is characteristic of the plates of both species. The boundaries of the two types of mesophyll are clearly visible due to the passage between them of the central vein, formed by a single conducting beam.

The presented general plan of the anatomical structure of the central leaves of the complex leaves of the two species of Melilotus can be differentiated by adding a description of the specific features. The specificity of the plates of each type lies in the number of layers of mesophyll cells, in the ratios of linear dimensions of palisade cells. For example, Melilotus albus plates have palisade cells that are 1 to 3 in size. For Melilotus officinalis leaves, this ratio is at least 1 to 4 , some cells are long and narrow, and the dependence of linear dimensions can be calculated as 1 to 5 . The following features Yellow clover plates are directly related to the relative sizes of palisade cells -the palisade volume takes up half of the volume of the photosynthetic parenchyma, and the spongy tissue is composed of, as a rule, three layers of cells (in some places -- four layers). A similar picture can be foreseen for Melilotus albus records. Smaller, palisade cell sizes determine the fact that the proportion of spongy chlorenchyma composed of four, and in some places and five rows of cells, occupies a larger volume in the thickness of the plate, compared with the volume of the columnar palisade (Fig. 1). 
A study of the physiological processes of the representatives of Melilotus officinalis determined the following picture. Drought resistance of the clover is reflected in the characteristics of its water regime. The total water content at the beginning of the dry period ( June) is $66 \%$, but at the height of the drought (end of July) it falls only to $58 \%$. It was also established that the intensity of transpiration increases from June to July -- from 179 to $270 \mathrm{mg} / \mathrm{g}$ per hour. Active transpiration, being the upper end motor, contributes to the efficient flow of water and protection from overheating. The total productivity of the plants was $26.5 \mathrm{~g}$ of wet weight and $9.4 \mathrm{~g}$ of dry weight; by the end of the growing season, the productivity indicators are increasing. The presented parameters reflect the good functioning of all the life processes of the plant during the summer drought.

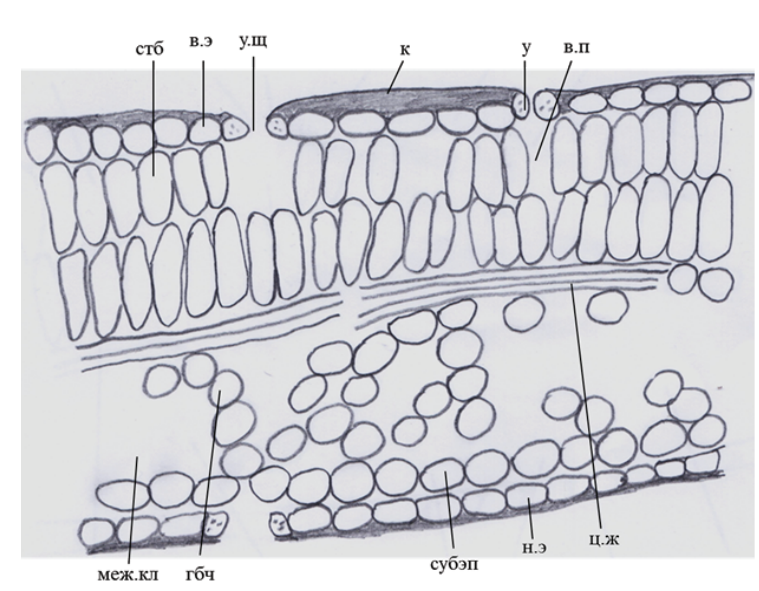

(a)

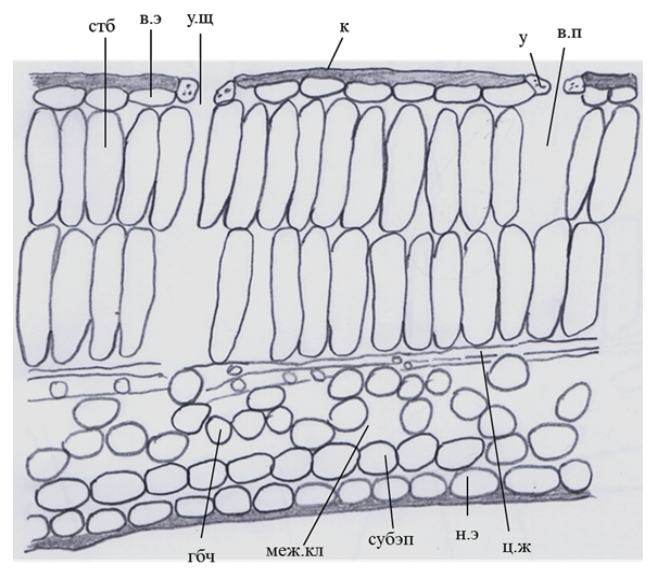

(b)

Figure 1: The schematic structure of the cross section of the leaf blade: (a) -- Melilotus albus; (b) -- Melilotus officinalis.

ст6. -- cells of the columnar chlorenchyma, у.щ. -- stomatal gap, y. -- the stomata closing cells, к. -- the cuticular layer of the upper epidermis, В.э. -- upper epidermis, В.п. -- air cavity in the area of stomata, ц.ж. -- central vein, меж.кл. -- intercellular, суб.эп. -- subepidermal layer of cells of the spongy parenchyma, н.э. -- lower epidermis, гбч. -- cells of spongy tissue.

\section{Conclusion}

Under the conditions of Kalmykia, representatives of Melilotus officinalis are characterized by larger specimens, compared with representatives of Melilotus albus. Yellow clover forms higher stems, with a greater number of side shoots and leaf blades. The inflorescences of the representatives of Melilotus albus, compared to the inflorescences of Melilotus officinalis, are longer, are composed of larger flowers, but the total number of flowers in one inflorescence is lower. Melilotus officinalis flowers ripen faster and bloom longer than those of Melilotus albus. 
The common features in the anatomical structure of the plates of both species are the presence of a dorzoretral type of mesophyll, the formation of two layers of palisade chlorenchyma and a subepidermal row of spongy tissue cells. In addition, on the border of palisade and spongy chlorenchyma, there passes the central vein composed of one bundle. The Melilotus albus plates have palisade cells that are 1 to 3 in size. The proportion of spongy chlorenchyma composed of four, and in some places and five rows of cells, occupies a larger volume in the thickness of the leaf, compared to the volume of the columnar palisades. For Melilotus officinalis leaves, the ratio of linear dimensions of palisade cells is at least 1 to 4 . The palisade volume takes up half of the volume of the photosynthetic parenchyma, and the spongy tissue is folded, as a rule, by three layers of cells (in some places -- four layers).

The described morphological and physiological characteristics of the two species of clover allow them to be defined as plants well adapted to grow under the arid conditions of Kalmykia. The combination of the structural features of the clover with its physiological capabilities, valuable feeding properties and a positive effect on the soil, testifies to the effectiveness of the use of clover in lean, saline areas. Along with other reducing plants, such as Krascheninnikovia or medick, the cultivation of clover in the region will contribute to the restoration of degraded land.

\section{References}

[1] Zelenev, A.V. (2009). Onobrychis and Melilotus productivity in the lower Volga area field crop rotation. News of the Nizhnevolzhsky agrouniversity complex: science and higher professional education, no. 4, pp. 4--10.

[2] Shashkarov, L.G. (2005). Selection of cover crops for donnik yellow. Agriculture, no. 3, pp. 26--27.

[3] Kolyasnikova, N.L. (2013). The flowering and seed production species of Melilotus albus and Melilotus officinalis. Middle East journal of scientific research, no. 11, pp. 1466--1469.

[4] Osina, E.A. (2017). Comparative study of the donnik medical and donnik white, growing in the Volgograd region. Actual problems of experimental and clinical medicine, ed V. Shumatov. Chapter 75. Volgograd: Volgograd State Medical University, pp. 499--500.

[5] Borlikov, G.M., Lachko, O.A., Bakinova, T.I. (2000). Ecology. Nature use of arid territories. Postov: SKNC VSh. 
[6] Tashninova, L.N. (2000). Red Book of Soils and Ecosystems of Kalmykia. Elista: APP Jangar.

[7] Demarchuk, G.A. (2005). Donnik as a sideral culture in forage crop rotations of the forest-steppe zone of Siberia. Feed production, no. 8, pp. 19--22.

[8] Chukhlebova, N.S. (2005). Donnik -- soil fertilizer restores. Problems of crop production on reclaimed land ed I Pogorelova. Stavropol: AGRUS, pp. 452--455.

[9] Dospekhov, B.A. (1973). Field experience. Moscow: Ear.

[10] Barykina, R.P., Kostrikova, L.N., Trankovskiy, D.A. (1979). Practical methods on plant anatomy. Moscow: High school.

[11] Plotnikova, I.V., Zhivukhina, E.A., Mikhalevskaya, O.B. (2001). Practical methods on plant physiology. Moscow: Academy. 